\title{
CASE COMMENT: \\ CANADA (ATTORNEY GENERAL) v. ROGER M. BOURBONNAIS PROFESSIONAL CORPORATION
}

\author{
DAVID J. STRATTON, Q.C. ${ }^{*}$ and DEBBIE L. HUGHES ${ }^{*}$
}

\section{INTRODUCTION}

A fundamental principle of corporate law is that of the limited liability it affords to the shareholders of a corporation. The courts have been loathe to lift the "corporate veil" to make a shareholder liable for obligations of the corporation except in the more extreme cases of shareholder misconduct.

In 1975, Bill $68^{1}$ was introduced in the Alberta Legislature allowing for the incorporation of professional corporations under each of the Chartered Accountants Act, ${ }^{2}$ the Dental Association Act, ${ }^{3}$ the Legal Profession Act, ${ }^{4}$ and the Medical Profession Act. ${ }^{5}$ In each of these cases, the legislation specifically provided that the individual holder of a license or permit for each of those professions may incorporate and practice his or her professional practice as a corporate entity. Unlike other entities incorporated under the Alberta Business Corporations Act $^{6}$ (or the then Companies $A c t$ ), the ability of a professional corporation to carry on its practice is very much tied to the individual professional who is its shareholder. To what extent the concept of limited liability shrouds the professional corporation, and particularly as that limited liability relates to third party obligations of the professional corporation, has not been examined by the courts very often or with a great deal of consistency in terms of the results.

Simply put, a professional corporation is incorporated under, and maintains its corporate existence under, the Business Corporations Act (or, previously under the Companies $A c t$ ). A professional corporation is permitted to carry on a professional practice under the Chartered Accountants Act, the Dental Association Act, the 1990 Legal Profession Act or the Medical Profession Act if the professional corporation obtains a permit from the governing body of that profession. A condition of the issuance of the permit to the professional corporation is that each voting shareholder must be a member of the profession. During the time that a professional corporation holds a permit, the shareholders are subject to the greater liability prescribed by $\mathbf{s}$. 129(1) of the Legal Profession Act for shareholders of the professional corporation (or

\footnotetext{
Partner, Lucas, Bowker \& White, Edmonton, Alberta.

.- Associate, Lucas, Bowker \& White, Edmonton, Alberta.

1 Bill 68, The Attorney General Statutes Amendment Act (No. 2), 2nd Sess., 18th Leg., Alberta, 1975.

R.S.A. 1980, c. C-5 [hereinafter Chartered Accountants Act].

R.S.A. 1980, c. D-7 [hereinafter Dental Association Act].

R.S.A. 1980, c. M-12 [hereinafter Medical Profession Act].

R.S.A. 1980, c. L-9 [hereinafter 1980 Legal Profession Act]. Now S.A. 1990, c. L-9.1 [hereinafter 1990 Legal Profession Act].

S.A. 1981 , c. B-15 [hereinafter Business Corp. Act].
} 
the equivalent provision in the other three statutes). The issue becomes what is the extent of that greater liability. ${ }^{7}$

The issue of whether a principal of a professional corporation is liable for the income tax of the professional corporation was examined by the Alberta Court of Appeal in the case of Canada (Attorney General) v. Roger M. Bourbonnais Professional Corp. ${ }^{8}$ The facts of the case are as follows. Bourbonnais practiced law through his professional corporation until 1981, when he ceased practicing through that professional corporation. Federal corporate income tax remained outstanding on the professional corporation's income for the 1982 taxation year, and the Attorney General of Canada commenced an action against both Bourbonnais and the professional corporation for the taxes owing by the professional corporation. Apparently, there was no claim for unpaid provincial corporate income tax. At issue was the specific wording of, and the interpretation of, s. 116(1) of the 1980 Legal Profession Act (now s. 129(1) of the 1990 Legal Profession Act).

\section{JUDGMENT}

Andrekson J., for the Court of Queen's Bench, considered the wording of the relevant section of the Legal Profession Act before concluding that Bourbonnais, as principal of the professional corporation, was not personally liable for the outstanding income tax for that corporation, and that s. 116(1) excluded liability for corporate tax. ${ }^{9}$ The only issue on appeal was the interpretation of s. 116(1) of the Act (which by then had changed to s. 129(1)). Section 116(1) read as follows:

Notwithstanding anything to the contrary in the Companies Act [now the Business Corporations Act], every person who is a shareholder of a corporation during the time that it is the holder of a permit or of a corporation during the time it acts in contravention of section 93(1) is liable to the same extent and in the same manner as if the shareholders of the corporation were during that time carrying on the business of the corporation as a partnership or, if there is only one shareholder, as an individual practising as a barrister or solicitor. ${ }^{10}$

Section 116(1) has been interpreted in this case, as well as in earlier decisions of the Court of Queen's Bench of Alberta, by determining the issue of how closely the particular liability in question of the corporation is related to the professional's practice. For instance, in Bancorp Financial Ltd. v. Thomas N. Mather Professional Corp.," Stratton J., as he then was, considered a similar circumstance involving a professional corporation holding a permit under the Dental Association Act. That legislation contains wording that is essentially similar to that contained in the Legal Profession Act. In interpreting that statute, emphasis was placed on the words "as an individual practicing

It should also be noted that under the 1990 Legal Profession Act, supra note 5, the liability of shareholders of a professional corporation is limited to voting shareholders.

(1996), 39 Alta. L.R. (3d) 17 (C.A.) [hereinafter Bourbonnais].

Ibid. at 19 (para. 4).

1980 Legal Profession Act, supra note 5, s. 116(1).

(1985), 36 Alta. L.R. (2d) 92 (Q.B.) [hereinafter Mather]. 
dentistry or dental surgery" at the end of the section. ${ }^{12}$ Attributing to these words only the plain ordinary meaning, liability was limited to obligations arising out of a dentistry practice. It was suggested by Stratton J. that, had the legislative intent been different, the drafter would have been able to end the section with the words "as an individual." Thus, Stratton J. found that the interpretation on the plain and ordinary meaning of the words used naturally limits liability of the principal to those obligations arising from the professional practice itself. ${ }^{13}$

The interpretation by Stratton J. in Mather is adhered to in each of the following cases:

(1) In Corkery v. Foster Wedekind, Virtue J. considered s. 116(1) of the 1980 Legal Professional Act in light of the corporation's liability for wages and benefits of employees of the professional corporation, and determined that these costs were directly associated with the practice of a barrister and solicitor. The individual principal was therefore also personally liable; ${ }^{14}$

(2) In Edmonton Telephones Corp. v. Monette, Funduk M. determined that telephone services did directly relate to the carrying out of the professional services of an accountant, and therefore the individual was liable for the professional corporation's telephone utility debt; ${ }^{15}$

(3) In Alberta v. Fletcher Estate, the court was once again in the position of considering the provisions of the Chartered Accountants Act. The professional corporation owed provincial income tax on income arising out of the practice of the individual accountant. Lutz $\mathrm{J}$. concluded in that case that liability for the tax arose from the practice of chartered accountancy, and as well, income tax was an effect of the practice whether or not the individual practiced through a professional corporation. ${ }^{16}$

It is on a distinction of the Fletcher Estate case that the Bourbonnais decision is decided. The Court of Appeal in Bourbonnais determined that income tax does not arise necessarily from the professional practice, but arises as a result of the Canada Income Tax $\mathrm{Act}^{17}$ which imposes the tax on income earned without regard to the nature of the business generating the income. The Court of Appeal pointed out that s. 116(1) of the 1980 Legal Professional Act contains the words "is liable to the same extent and in the same manner...," and in giving meaning to this phrase concluded that Bourbonnais could not be liable for the tax obligations of the professional corporation. The Court relied on the very different treatment afforded corporations and individuals under the

Dental Association Act, supra note 3, s. 77(1).

Mather, supra note 11 at 94.

(1987), 56 Alta. L.R. (2d) 268 (Q.B.) [hereinafter Corkery].

(1994), 160 A.R. 72 (Q.B. Master).

(1994), 27 Alta. L.R. (3d) 384 (Surr. Ct.) [hereinafter Fletcher Estate].

R.S.C. 1985, c. 1 (5th Supp.) [hereinafter Income Tax Act]. 
Income Tax Act to suggest that the corporation and the individual cannot be liable in the same manner and to the same extent as each other for such tax. ${ }^{18}$

\section{ANALYSIS AND SUMMARY}

At first glance, the reasoning of Lutz J. in Fletcher Estate seems preferable to the reasoning of the Court of Appeal in Bourbonnais. The issue before Lutz J. was whether a shareholder of a professional corporation which carried on the practice of chartered accountancy was liable for provincial corporate income tax which arose from the practice of the professional corporation. As noted by the Court of Appeal in Bourbonnais, Lutz $\mathrm{J}$. observed that the payment of taxes to the province is a consequence of a profitable accounting practice whether that practice is carried on through a professional corporation or directly by an individual. Lutz J. also observed that because of the concept of integration in our tax system, it should be "tax neutral" whether a professional practice is carried on directly by an individual or through a corporation. ${ }^{19}$ In other words, the amount of tax payable should be approximately the same whether the practice is carried on by an individual or by a professional corporation. At the time that the amendments were made to the Chartered Accountants Act, the Dental Association Act, the Legal Profession Act and the Medical Profession Act in 1975, integration was not as refined as it is today and there was an advantage to carrying on a practice through a corporation rather than individually as a sole proprietorship or through a partnership. The crux of the decision of Lutz J. in Fletcher Estate, as quoted by the Court of Appeal in Bourbonnais, is as follows:

The combined tax owed by the Professional Corporation and owed by Fletcher on the distributions received from the corporation is an amount similar to the amount that would have been owed by Fletcher had he conducted his business as a sole proprietorship and earned the money directly. Whether or not Fletcher had organised as a corporation he would have been subject to the same or similar tax liability.

Thus, as the Professional Corporation's liability to pay provincial tax arose from the income generated by the practice of accounting and as the liability to pay provincial tax would arise no matter what form of business organization was selected by Fletcher, I conclude that the liability to pay provincial taxes is a liability that arose from the practice of accounting and is one for which Fletcher's estate is liable. ${ }^{20}$

The Court of Appeal in the Bourbonnais decision disagreed with the conclusion of Lutz $\mathrm{J}$. and adopted the argument of counsel for Bourbonnais to the effect that:

(1) The obligation of a professional corporation to pay income taxes does not arise from the professional practice but rather flows from the provisions of the Income Tax Act which imposes a tax on business income after it has been 
earned and without reference to the character of the business in which it was earned;

(2) The Income Tax Act provides a scheme by which corporations and individuals are treated as separate and distinct taxpayers subject to different rules for the computation of income and different rates of tax. Thus, as it is put in the argument of counsel for Bourbonnais which was adopted by the Court of Appeal, individuals and corporations can never be "liable" (as counsel for Bourbonnais put it) or "taxed" (as the Court of Appeal put it) "to the same extent and in the same manner" as a corporation for income tax and vice versa. $^{21}$

Counsel for the Attorney General of Canada in Bourbonnais accepted the proposition in Corkery v. Foster Wedekind that the statutory liability is not limited solely to matters arising out of the carrying out of professional duties but also arises out of "the directness of the connection to the practice of law in the broader sense to which this section has application."22 Counsel for the Attorney General in Bourbonnais argued that the decision in Mather is too broadly stated by Stratton J. where he interpreted the statute as restricting the liability of the shareholder of a professional corporation to those activities which related to the practice. Not surprisingly, counsel for the Attorney General adopted the reasoning in Fletcher Estate that a shareholder is liable for payment of the provincial corporate income tax which arises from the income generated by the professional practice or, in other words, the tax liability flows directly from the income generated by the professional practice. ${ }^{23}$

In the decisions that relate to the liability of a shareholder of a professional corporation for the liabilities of the professional corporation, reference is made either directly or indirectly to the intention of the Legislature when the amendments to the four professional statutes were made in 1975. It is interesting to review Hansard on the debates about Bill 68 which amended the four statutes. At first reading by the Legislature, the proponent of Bill 68 stated that the purpose is to allow persons who are carrying on business as chartered accountants, dentists, lawyers and medical doctors to form a professional corporation for the conduct of their profession. That will allow the four professions "the privilege of incorporation that other professions and individuals already enjoy, and will remove discrimination under the income tax laws. ${ }^{24}$

During second reading, the proponent referred to "some misunderstanding or misinterpretation, publicly and in the media, as to what the Bill really does." 25 According to the Bill's proponent, the key issue with Bill 68 before it was introduced in the Legislature concerned the maintaining of the professional relationship between

Bourbonnais, supra note 8 at 21-22 (paras. 12-17).

Corkery, supra note 14 at 270.

Bourbonnais, supra note 8 at 19-21 (para. 11).

Alberta, Legislative Assembly, Hansard, 1st Sess., 18th Leg., (26 November 1975) at 1323.

Ibid. (4 December 1975) at 1406. 
the four professions and their clients or patients. That hurdle was overcome by ensuring that "you didn't limit their liability to their customers or patients. A clause in the bill would maintain their liability in the form that it was prior to the [incorporation] of the practice. ${ }^{.126}$ The debate turned towards whether allowing incorporation would give an unfair tax advantage to those professionals, as at the time of second reading of the Bill the Legislature was considering legislation which would (and did) authorize the participation of the Province in the federal wage and price guidelines for a further period of time. The argument made by the opposition in the Legislature was that the effect of Bill 68 allowed the four professions to avoid the wage and price legislation. ${ }^{27}$ The proponents of Bill 68 argued that the intent of the Bill was to even out for those professionals the "high points and the low points" of his or her practice by allowing the individual to leave professional income within the professional corporation where it is taxed at a lower rate rather than having the professional income paid out directly to the individual where it is taxed at a high rate. ${ }^{28}$ An opposition member also argued that the effect of the legislation would be a tax drain on the Alberta Treasury. ${ }^{29}$

It is interesting that the debates did not focus on liability of the professional corporation to third parties. Rather the debates in the Legislature focused on the income tax aspects of the legislation and the necessity of ensuring that the professional relationship between the client or patient and the professional is unaffected where the practice is carried on through a professional corporation. In light of the debates as recorded in Hansard it would appear that what the Legislature intended by the phrase that a person is liable "to the same extent and in the same manner ... as an individual practicing as a barrister and solicitor" is the liability which the professional has to a client or patient and not to third party liability.

It therefore seems clear that the intention of the Legislature in 1975 was to put individuals who practice as lawyers, chartered accountants, medical doctors and dentists in the same position as those other professions, such as engineers, ${ }^{30}$ that can carry on their professional practice through a corporation without the individual shareholders being exposed to personal liability. It may be argued that not only is Bourbonnais correctly decided, but also that Corkery v. Foster Wedekind and Edmonton Telephone Corp. v. Monette are incorrectly decided. A shareholder of a corporation incorporated under the Business Corporations Act is not liable to pay employee benefits due to an employee of the corporation or company, nor is the shareholder obligated to pay the lease obligations of a corporation to a supplier of equipment used by the corporation, in the absence of some independent personal covenants to do so, or some other independent statutory or equitable obligation.

Ibid. at 1407.

Ibid.

Ibid. at 1408.

Ibid. (15 December 1975) at 1624.

The example of engineers was used in the debates in the Legislature, e.g., ibid. (4 December 1975) at 1407. 


\section{CONCLUSION}

The prevailing rule of statutory interpretation as stated by the Supreme Court of Canada in Corp. Notre-Dame de Bon-Secours v. Communauté Urbaine de Québec and the City of Québec is that a legislative provision should be given a strict or liberal interpretation depending upon the purpose underlying it and that purpose must be identified in light of the context of the statute, its objective, and the legislative intent. ${ }^{31}$

The intent of the Legislature in 1975 was to place professional corporations on the same footing as other corporations while preserving the fundamental aspects of the professional relationship with the professional's clients or patients. It was not intended to provide third parties, including Revenue Canada and Alberta Treasury, with an ability to attach personal liability to the shareholders of professional corporations solely on the basis of shareholder status. The provision should be given a strict interpretation to the extent that it increases a shareholder's liability. That interpretation is consistent with the phrase in the Legal Profession Act cited above (and the similar phrases in the other three statutes) that a shareholder or professional corporation is liable "to the same extent and in the same manner ... as an individual practicing as a barrister and solicitor."

\section{Thus as Stratton J. put it in Mather:}

The result of this interpretation is that the dentist in a professional corporation is liable only for those activities related to his dental practice such as a breach of his professional duties. ${ }^{32}$

The Court of Appeal in Bourbonnais may have focused too much on the argument that the Income Tax Act treats taxes payable by an individual in a different manner than income taxes payable by a corporation. Perhaps the Court of Appeal should have gone back to first principles and provided guidance as to whether the provisions of s. 116(1) of the 1980 Legal Profession Act and the similar provisions in the other three statutes should be construed as imposing liability on the individual shareholder solely to patients and clients, rather than to third parties including those third parties who are providing goods and services to enable the professional corporation to carry on its professional practice. This would then put those practitioners of the four professions in the same position as shareholders of corporations that carry on other professional practices so far as third party liability is concerned.

A third party supplier of goods and services is always at liberty to ask for a guarantee or indemnity from shareholders of a corporation that the supplier deals with. Was it really the intent of the Legislature, as assumed by the Court of Queen's Bench, to impose a statutory guarantee by shareholders of a professional corporation in favour of suppliers of goods and services during the time period the professional corporation holds a permit to practice? 
The Court of Appeal in the Bourbonnais decision expressly disagreed with the finding in Fletcher Estate. Perhaps the Court of Appeal should consider whether Corkery v. Foster Wedekind and Edmonton Telephones Corp v. Monette have been correctly decided by the Court of Queen's Bench of Alberta. 